\title{
Pengaruh Pengumuman Perubahan Harga BBM terhadap Abnormal Return dan Trading Volume Activity pada Perusahaan-Peruasahaan yang Tergabung dalam Kelompok LQ 45 Dibursa Efek Indonesia periode 2015-2016
}

\author{
Denny Asmas ${ }^{1}$ \\ Fakultas Ekonomi Universitas Batanghari ${ }^{1}$
}

\begin{abstract}
The increase in the price of Fuel (BBM) can zoom in on the burden of the community and the business world. Vice versa, the drop in the price of fuel not only lighten the load of the community but also for the business world. Announcements containing information (information content), expected the market will react at the time the announcement was welcomed by the market. Market reaction is indicated by the existence of changes in prices of the securities in question. This research was conducted to find out whether there are abnormal return there is a difference, the difference in stock trading volume activity, abnormal return of shares and trading volume of activity before and after the events of the increase in the price of fuel oil. This research is quantitative research by doing event study. The population in this research is the stocks category LQ-45 period of March 2015 to April 2016 with a sample of companies that have listed on the Group Index LQ 45 period November 2014 and March 2015 and don't do Corporate Action. The results of hypothesis testing of research it can be concluded that there is a significant difference between the Abnormal Return (AR) and Trading Volume Activity (TVA) and events before and after the events of rising fuel prices, then there is no a significant difference between the Abnormal Return (AR) and between Trading Volume Activity (TVA) and event announcements of events before and after the drop in the price of fuel.
\end{abstract}

Keywords: Fuel oil, Abnormal Return and Trading Volume Activity (TVA)

\section{PENDAHULUAN}

Pada era globalisasi saat ini, kebijakan pemerintah berkaitan erat dengan stabilitas perekonomian suatu negara, salah satunya kebijakan pemerintah adalah menaikkan harga bahan bakar minyak (BBM) yang pada akhirnya juga akan berdampak pada perekonomian. Walaupun tidak berpengaruh langsung dengan dinamika yang terjadi di pasar modal, tetapi kenaikan harga bahan bakar minyak (BBM) tidak bisa dipisahkan dari aktivitas bursa saham. Semakin pentingnya peran bursa saham dalam kegiatan ekonomi, membuat bursa semakin sensitif terhadap berbagai peristiwa di sekitarnya, baik berkaitan ataupun tidak berkaitan secara langsung dengan isu ekonomi.

Bahan bakar minyak memiliki peranan yang sangat penting sebagai bahan yang mendukung proses produksi bagi industri yang pada akhirnya menggerakkan perekonomian. Kenaikkan harga BBM bagi industri membuat beban biaya produksi meningkat yang selanjutnya berdampak pada penurunan tingkat keuntungan perusahaan. Selain itu kenaikan harga BBM juga mempengaruhi harga barang kebutuhan masyarakat yang semakin mahal sehingga menurunkan daya beli masyarakat dan akan menurunkan hasil penjualan atau menurunkan tingkat laba perusahaan.

Di Indonesia sendiri pemerintah telah beberapa kali melakukan perubahan harga BBM dari tahun 2005 sampai dengan sekarang, antara lain pada 1 Maret 2005 pemerintah menaikkan premium dari Rp 1.850 menjadi Rp 2.400 per liter. Sementara harga solar naik dari Rp 1.650 menjadi Rp 2.100 per liter. Pada 1 Oktober 2005, harga premium dan solar kembali dinaikkan. Harga premium naik dari Rp 2.400 menjadi Rp 4.500 per liter. Sedangkan solar dari Rp 2.100 menjadi Rp 4.300 per liter. Kemudian pada 24 Mei 2008, pemerintah kembali menaikkan harga premium menjadi Rp 6.000 per liter dan solar Rp 5.500 per liter. Pada tanggal 22 Juni 2013 harga premium naik kembali dari Rp 6.000 menjadi Rp 6.500 dan solar tetap pada Rp 5.500 per liter. Pada tanggal 18 November 2014 pemerintah kembali menaikkan harga premium dari Rp 6.500 menjadi Rp 8.500 per liter. Sedangkan solar menjadi Rp 7.500 per liter. Pada tahun 2015 pemerintah kembali menaikkan BBM sebanyak 2 kali yaitu pada tanggal 1 Maret premium naik menjadi Rp 6.800 per liter sedangkan harga solar tetap Rp 6.400 per liter dan pada tanggal 28 Maret pemerintah kembali 
menaikkan premium menjadi Rp 7.300 per liter dan solar naik menjadi Rp 6.900 per liter.

Pemerintah Indonesia ternyata ada juga menurunkan harga BBM. Pada tahun 2009 yaitu mendekati pemilihan umum (pemilu), pemerintah menurunkan harga BBM tiga kali dalam waktu 1,5 bulan yaitu pada 1 Desember 2008, harga premium turun Rp 500 menjadi Rp 5.500 per liter sedangkan harga solar tetap Rp 5.500 per liter. Pada 15 Desember 2008, harga premium kembali turun Rp 500 per liter menjadi Rp 5.000 per liter dan solar turun $\mathrm{Rp} 700$ menjadi Rp 4.800 per liter. Kemudian pada 15 Januari 2009, harga premium dan solar keduanya turun menjadi Rp 4.500 per liter. Pada tahun 2015, pemerintah menurunkan hanga BBM sebanyak dua kali yaitu pada tanggal 1 Januari harga premium dari Rp 8.500 per liter menjadi Rp 7.600 per liter sedangkan solar dari Rp 7.500 per liter menjadi $\mathrm{Rp} 7.250$ per liter. dan pada tanggal 19 Januari premium turun kembali menjadi Rp 6.700 per liter dan solar turun menjadi Rp 6.400 per liter. Terakhir pada tahun 2016 pemerintah kembali menurunkan harga BBM sebanyak dua kali yaitu pada tanggal 5 Januari premium turun menjadi Rp 7.050 per liter dan solar turun menjadi Rp 5.650 per liter dan pada tanggal 1 April premium turun kembali manjadi Rp 6.550 per liter dan solar turun menjadi Rp 5.150 per liter.

Penurunan harga BBM bukan saja meringankan beban masyarakat kecil pada umumnya tetapi juga bagi dunia usaha pada khususnya. Dampak dari penurunan harga BBM adalah penurunan pada biaya produksi. Penurunkan biaya produksi akan mengakibatkan penurunan harga pokok produksi dan selanjutnya menurunkan harga jual produk sehingga meningkatnya tingkat keuntungan dari suatu perusahaan, artinya peristiwa tersebut direspon positif oleh para pelaku ekonomi atau pelaku pasar.

Pengumuman yang mengandung informasi (information content), diharapkan pasar akan bereaksi pada waktu pengumuman tersebut diterima oleh pasar. Reaksi pasar ditunjukkan dengan adanya perubahan harga dari sekuritas bersangkutan. Reaksi ini dapat diukur dengan menggunakan return sebagai nilai perubahan harga atau dengan menggunakan abnormal return. Jika digunakan abnormal return, maka dapat dikatakan bahwa suatu pengumuman yang mempunyai kandungan informasi akan memberikan abnormal return kepada pasar. Sebaliknya yang tidak mengandung informasi maka tidak memberikan abnormal return kepada pasar.

\section{METODE PENELITIAN}

Berdasarkan jenis data dan analisisnya, penelitian ini adalah penelitian kuantitatif, dimana penelitian ini merupakan data sekunder, yaitu data diperoleh atau dikumpulkan dari penelitian orang lain atau sumber yang telah dipublikasikan.

Jenis penelitian ini adalah penelitian event study yang dilakukan dengan mengamati pengaruh dari suatu kejadian tertentu pada periode tertentu. Tanggal peristiwa yang dipublikasikan ditetapkan sebagai event day $(\mathrm{t}=0)$, dengan melihat tanggal pada pengumuman perubahan harga BBM. Event Study digunakan untuk menguji kandungan informasi dari suatu peristiwa pengumuman (information content).

Peristiwa yang diuji dalam penelitian ini yaitu peristiwa pengumuman kenaikandan penurunan harga BBM pada periode Maret 2015 sampai April 2016.Informasi dari pengumuman perubahanharga BBM akan diuji pengaruhnya terhadap reaksi pasar modal yang diproksikan terhadap abnormal return, dan volume perdagangan saham.

\section{Populasi dan Sampel \\ Penentuan Populasi}

Populasi dalam penelitian ini adalah saham-saham kategori LQ-45 periode Maret 2015 sampai April 2016

\section{Penentuan Sampel}

Teknik pengambilan sampel yang digunakan dalam penelitian ini diambil dengan metode purposive sampling. Kriteria yang digunakan untuk memilih sampel dalam penelitian ini antara lain:

1. Perusahaan-perusahaan tersebut telah terdaftar pada kelompok Indeks LQ 45 periode November 2014 dan Januari 2015 karena saham-saham tersebut merupakan saham yang memiliki tingkat likuiditas tinggi di BEI.

2. Perusahaan tidak melakukan Corporate Action seperti pengumuman deviden, pengumuman laba, right issue, stock split, dan lain-lain selama periode penelitian. Karena agar tidak terjadi confounding effect yaitu reaksi pasar terhadap peristiwa lain yang berdekatan dengan peristiwa yang sedang diteliti. 
Alasan digunakannya perusahaan yang masuk dalam kategori LQ 45 sebagai sampel dalam penelitian ini yaitu dikarenakan perusahaan- perusahaan yang masuk dalam kategori ini merupakan 45 perusahaan yang memiliki tingkat likuiditas yang tinggi sehingga reaksi pasar yang terjadi akibat perubahan harga BBM dapat terlihat lebih jelas dan akurat.

Variabel independen dalam penelitian ini adalah peristiwa pengumuman perubahan harga BBM yang diproksikan terhadap peristiwa pengumuman harga BBM yaitu periode Maret 2015 sampai April 2016 sedangkan variabel dependen terdiri dari dua macam antara lain data mengenai abnormal return saham dan trading volume activity (TVA).

1. Abnormal Return

Menurut Samsul (2006:275) abnormal return adalah selisih antara return aktual dan return yang diharapkan (expected return) yang dapat terjadi sebelum informasi resmi diterbitkan atau telah terjadi kebocoran informasi (leakage of information) sesudah informasi resmi diterbitkan. Untuk menghitung abnormal return dapat menggunakan rumus sebagai berikut:

$$
R T N_{\mathrm{i}, \mathrm{t}}=R_{\mathrm{i} . \mathrm{t}}-E\left(R_{\mathrm{i} . \mathrm{t}}\right)
$$

Notasi:

$R T N_{\mathrm{i}, \mathrm{t}}=$ abnormal return $\operatorname{sekuritas}(i)$ pada periode ke- $t$

$R_{\mathrm{i}, \mathrm{t}}=$ actual return sekuritas (i) pada periode ke- $t$

$E\left(R_{\mathrm{i} . \mathrm{t}}\right) \quad=$ terurn pasar pada periode ke- $t$ Actual return individual saham dirumuskan dengan persamaan:

$$
R i, t=\frac{P i, \mathrm{t}-P i, \mathrm{t}-1}{P i, \mathrm{t}-1}
$$

Notasi:

$R_{\mathrm{i}, \mathrm{t}}=$ return individual saham ke- $i$ pada hari $t$

$P_{i, \mathrm{t}}=$ closing price pada hari $t$

$P_{i, \mathrm{t}-1}=$ closing price pada hari $t-1$
Sedangkan Perubahan Harga BBM pada periode ke-t dirumuskan sebagai berikut:

\begin{tabular}{|c|c|}
\hline $\begin{array}{l}\triangle \text { Harga } B L \\
B B M \text { ke- } t\end{array}$ & $=$ Perubahan harga \\
\hline $\begin{array}{l}B B M_{t} \\
\text { hari ke-t }\end{array}$ & $=$ Perubahan harga BBMpada \\
\hline$B B M_{t-1}$ & $=$ Perubahan harga BBM pada \\
\hline
\end{tabular}

$$
\begin{aligned}
& \Delta \text { Harga } B B M=\underline{B B M_{t}}-\underline{B B M_{t-1}} \\
& B B M_{t-1}
\end{aligned}
$$

Notasi:

2. Trading Volume Activity (TVA)

Trading volume activity (TVA) digunakan untuk melihat perubahan atas likuiditas saham. Untuk menghitung TVA saham diperlukan data mengenai volume perdagangan dari jumlah saham beredar pada saat t, TVA dapat dirumuskan sebagai berikut:

$$
T V A=\frac{\text { volume perdagangan saham saat } t}{\text { Jumlah saham beredar saat } t}
$$

\section{HASIL DAN PEMBAHASAN}

Untuk mengetahui adanya autokorelasi digunakan uji Durbin-Watson, dengan dengan cara melihat besaran Durbin-Watson sebagai berikut : Angka D-W di bawah -2, berarti ada autokorelasi positif;Angka D-W diantara -2 sampai +2 , berarti tidak ada autokorelasi;Angka D-W di atas +2 , berarti ada autokorelasi negatif.

Hasil uji autokorelasi di atas menunjukkan nilai statistik Durbin-Watson (D-W) sebesar 1.369. Oleh karena nilai DW lebih kecil dari 2,(2 <1.369) maka disimpulkan bahwa tidak terjadi autokorelasi, maka penelitian ini layak untuk dilanjutkan.

\section{Multikolinier}

\begin{tabular}{|c|c|c|c|}
\hline Variabel & Toleransi & VIF & Keterangan \\
\hline$\Delta$ Harga BBM & 1.000 & 1.000 & Non Multikolinier \\
\hline Trading Volume Activity & 1.000 & 1.000 & Non Multikolinier \\
\hline
\end{tabular}

Identifikasi secara statistik ada atau tidaknya multikolinieritas dapat dilakukan dengan menghitung Variance Inflation Factor (VIF).

Tabel 1. Uji Multikolinieritas

Sumber : data olahan

Berdasarkan perhitungan di atas

diperoleh hasil bahwa nilai VIF pada seluruh 
variabelbebas lebih kecil dari 10,artinya seluruh variabel bebas pada penelitian ini tidakada gejala multikolinier (Gujarat, 1995, hal. 339).

\section{Heteroskedasitas}

Scatterplot

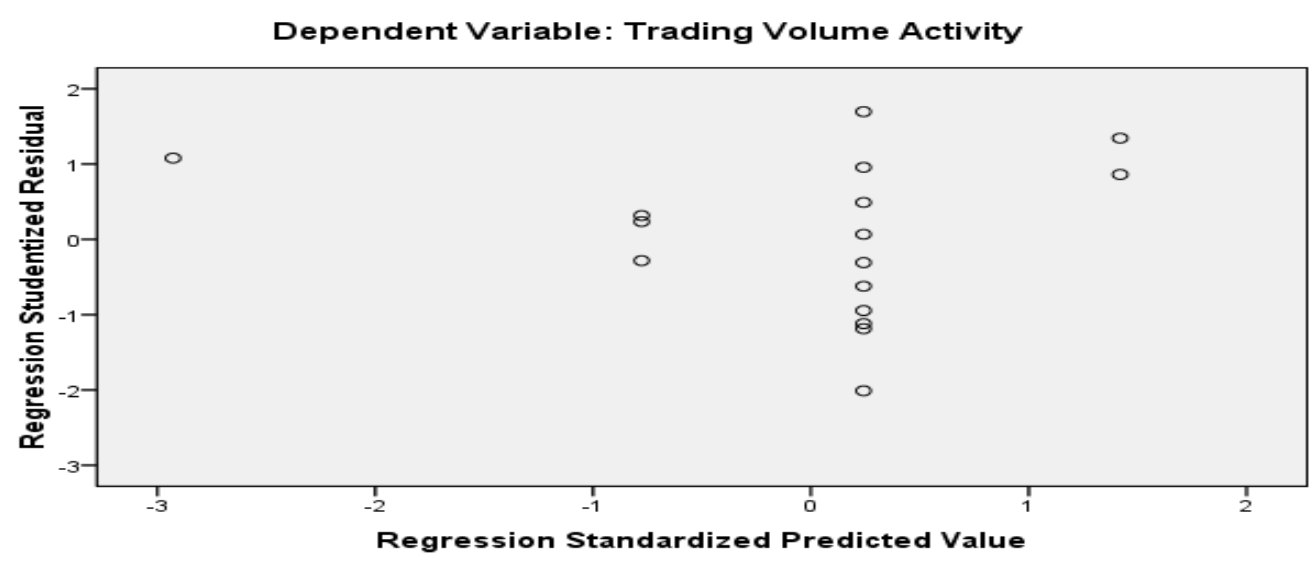

Gambar 1. Grafik Scatterplot Uji Heteroskedastisitas

Uji Heteroskedastisitas dilakukan dengan cara grafik, dari grafik Scatterplot yang disajikan yang terdapat pada gambar 1, yang terlihat titiktitik menyebar secara acak tidak membentuk sebuah pola tertentu yang jelas serta tersebar baik diatas maupun dibawah angka nol pada sumbu Y. Hal ini berarti tidak terjadi heteroskedastisitas pada model regresi.

\section{Analisis Data}

Untuk mengetahui pengaruh hubungan Perubahan Harga BBM $\left(\mathrm{X}_{1}\right)$ dan Trading Volume Activity $\left(\mathrm{X}_{2}\right)$ terhadap Abnormal
Return(Y), maka digunakan analisa regresi linier berganda yang dapat dirumuskan sebagai berikut:

$\mathrm{Y}=\mathrm{b}_{0}+\mathrm{b}_{1} \mathrm{X}_{1}+\mathrm{b}_{2} \mathrm{X}_{2}+\mathrm{b}_{3} \mathrm{X}_{3}+\mathrm{e}$

Dimana :

$\mathrm{Y}=$ Abnormal Return; $\mathrm{b}_{0}=$ Konstanta; $\mathrm{X}_{1}=$ Perubahan Harga BBM; $\mathrm{X}_{2}=$ Trading Volume Activity; $b_{1}, b_{2},=$ Koefisien Regresi; $\mathrm{e}=$ variabel penganggu di luar model.

Dari hasil perhitungan dengan menggunakan SPSS (Statistical Program for Social Science), maka didapat hasil uji F dan uji $\mathrm{t}$ seperti pada tabel 2. di bawah ini.

Tabel 2. Hasil Perhitungan Uji F dan Uji t

\begin{tabular}{lrrrr}
\hline \multicolumn{1}{c}{ Variabel } & Koefisien Regresi & Galat Baku & Uji t & $\mathrm{R}^{2}$ Partial \\
\hline$\Delta$ Harga BBM (X1) & 1.455 & 1.378 & 1.056 & 0.074 \\
Trading Volume Activity (X2) & 0.544 & 0.655 & 0.830 & 0.047 \\
Konstan & 3.806 & & & \\
F Hitung & 1.115 & & & \\
\hline
\end{tabular}

Sumber : data olahan

Berdasarkan tabel di atas diperoleh persamaan regresi linier berganda sebagai berikut :

$\mathrm{Y}=\mathrm{b}_{0}+\mathrm{b}_{1} \mathrm{X}_{1}+\mathrm{b}_{2} \mathrm{X}_{2}+\mathrm{e}$

$\mathrm{Y}=3.806+1.455\left(\mathrm{X}_{1}\right)+0.544\left(\mathrm{X}_{2}\right)$

Dari persamaan tersebut di atas dapat dijelaskan sebagai berikut :

Konstanta $\quad\left(b_{0}\right) \quad$ sebesar $\quad 3.806$ menunjukkan besarnya pengaruh hubungan $\Delta$ Harga BBM (X1) dan Trading Volume Activity
(X2) terhadap Abnormal Return (Y), artinya apabila variabel bebas tersebut sama dengan nol, maka diprediksikan Harga Saham (Y) sebesar 3,806 satuan.

Koefisien regresi untuk $\Delta$ Harga BBM (X1) sebesar 1,455. Berarti jika $\Delta$ Harga $\operatorname{BBM}\left(\mathrm{X}_{1}\right)$ naik sebesar 1 satuan, maka Harga Saham (Y) akan mengalami kenaikan sebesar 1,455 satuan. Dengan anggapan Trading Volume Activity $\left(\mathrm{X}_{2}\right)$ tetap. 
Koefisien regresi untuk Trading Volume Activity (X2) sebesar 0,544. Berarti jika Trading Volume Activity (X2) naik sebesar 1 satuan, maka Abnormal Return (Y) akan mengalami kenaikan sebesar 0,544 satuan dengan anggapan $\Delta$ Harga BBM (X1) tetap.

\section{Pengujian Hipotesis}

Untuk membuktikan kebenaran dari hipotesis yang diteliti, maka perlu diadakan pengujian hasil analisa tersebut dengan menguji ' $t$ ' dan uji ' $F$ ' yang dapat diuraikan sebagai berikut :

a. Untuk mengetahui pengaruh dari masingmasing variabel bebas secara parsial terhadap variabel terika digunakan analisi suji t.

Digunakanuntukmengetahuipengaruh secaraparsial yaitu $\Delta$ Harga BBM (X1)dan Trading Volume Activity $\left(\mathrm{X}_{2}\right)$ terhadap Abnormal Return (Y). Langkahlangkahpengujiannyaadalah sebagai berikut:

(1) $\triangle$ Harga BBM (X1)terhadap Abnormal Return (Y)

Hasil perhitungan menunjukkan $t_{\text {hitung }}$ sebesar 10,056

$\mathrm{H}_{0}:$ bi $=0$,tidak adapengaruh $\Delta$ Harga BBM (X1) terhadap Abnormal Return (Y)

$\mathrm{H}_{\mathrm{i}}$ :bi $\neq 0$, terdapatpengaruh $\Delta$ Harga BBM (X1) terhadap Abnormal Return (Y)

Kriteria penerimaan dan penolakan, yaitu :

$\mathrm{H}_{0}$ diterima bila -1 tabel $<\mathrm{t}_{\text {hitung }}<\mathrm{t}_{\text {tabel }}$

$\mathrm{H}_{0}$ ditolak bila $\mathrm{t}_{\text {hitung }}>\mathrm{t}_{\text {tabel }}$ atau $-\mathrm{t}_{\text {hitung }}<-1$ tabel

Karena $t_{\text {hitung }} 10,056>t_{\text {tabel }} 2,306$, maka $\mathrm{H}_{0}$ ditolak dan $\mathrm{H}_{\mathrm{i}}$ diterima,sehinggadapat disimpulkan bahwa $\triangle$ Harga $B B M$ (X1)tidak berpengaruh positif dansignifikan terhadap Abnormal Return (Y).

Nilai ' $r$ ' parsial untuk variabel $\Delta$ Harga BBM (X1) sebesar 0,074 berarti variabel bebas $\Delta$ Harga BBM (X1) mampu menjelaskan variabel Abnormal Return (Y) sebesar 7.4\%.

(2) Trading Volume Activity $\left(\mathrm{X}_{2}\right)$ terhadap Abnormal Return (Y)

Hasil perhitungan menunjukkan $\mathrm{t}_{\text {hitung }}$ sebesar 0,830
$\mathrm{H}_{0}$ : bi $=0$, tidak ada pengaruh Trading Volume Activity $\left(\mathrm{X}_{2}\right)$ terhadap Abnormal Return (Y)

$\mathrm{H}_{\mathrm{i}}:$ bi $\neq 0$, terdapat pengaruh Trading Volume Activity $\left(\mathrm{X}_{2}\right)$ terhadap Abnormal Return (Y)

Karena $-\mathrm{t}_{\text {tabel }}(-2,306)<\mathrm{t}_{\text {hitung }}(0,830)<$ $t_{\text {tabel }}(2,306)$, maka $\mathrm{H}_{0}$ ditolak ditolak, sehingga dapat disimpulkan bahwa Trading Volume Activity $\left(\mathrm{X}_{2}\right)$ tidak berpengaruh positif dan signifikan terhadap Abnormal Return (Y).

Nilai ' $r$ ' parsial untuk variabel Trading Volume Activity $\left(\mathrm{X}_{2}\right)$ sebesar 0,047 berarti variabel bebas Trading Volume Activity $\left(\mathrm{X}_{2}\right)$ mampu menjelaskan variabel Harga Saham (Y) sebesar 4.7\%.

b. Selanjutnya untuk mengetahui pengaruh simultan dari variabel bebas terhadap variabel terikat digunakan analisis uji $\mathrm{F}$.

Digunakan untuk mengetahui pengaruh secara simultan $\Delta$ Harga $B B M$ (X1) dan Trading Volume Activity $\left(\mathrm{X}_{2}\right)$ terhadap Abnormal Return (Y). Langkah-langkah pengujiannya adalah sebagai berikut:

$\mathrm{H}_{0}: \mathrm{b}_{1}=\mathrm{b}_{2}=\mathrm{b}_{3}=\mathrm{b}_{\mathrm{i}}=0, \Delta \operatorname{Harga}$ BBM (X1) Trading Volume Activity $\left(\mathrm{X}_{2}\right)$ tidak berpengaruh positif dan signifikansi terhadap Harga Saham (Y).

$\mathrm{H}_{\mathrm{i}}$ : salah satu dari $\mathrm{b} \neq 0, \Delta$ Harga BBM (X1) dan Trading Volume Activity $\left(\mathrm{X}_{2}\right) \mathrm{ada}$ pengaruh positif dan signifikansi terhadap Abnormal Return (Y)

Hasil perhitungan menunjukkan bahwa $F_{\text {hitungsebesar 1,115 }}$

Menggunakan taraf signifikan $\alpha=0,05$ danderajat kebebasan(df) $=(3 ; 8)$, sehinggadiketahui $\mathrm{F}_{\text {tabel }} 4,066$.

Kriteria penerimaan dan penolakan, yaitu :

$\mathrm{H}_{\mathrm{o}}$ ditolak, bila $\mathrm{F}_{\text {hitung }}>\mathrm{F}_{\text {tabel }}$

$\mathrm{H}_{\mathrm{o}}$ diterima, apabila $\mathrm{F}_{\text {hitung }}<\mathrm{F}_{\text {tabel }}$

Karena $F_{\text {hitung }}(1.115)<\mathrm{F}_{\text {tabel }}(4,066)$, maka $\mathrm{H}_{\mathrm{i}}$ diterima. Sehingga dapatdisimpulkan bahwa $\triangle$ Harga BBM (X1) dan Trading Volume Activity $\left(\mathrm{X}_{2}\right)$ secara simultan tidak berpengaruh positif dan signifikan terhadap Abnormal Return (Y). Nilai koefisien determinasi $\left(\mathrm{R}^{2}\right)$ dimana hasil perhitungan sebesar 2.272 atau $22.72 \%$ yang berarti variabel bebas $\mathrm{X}_{1}$, dan $\mathrm{X}_{2}$ dapatmenjelaskan variabel terikat (Y)sebesar $22.72 \%$,sedangkansisanya sebesar $77.28 \%$ 
dijelaskan oleh variabel lain yang tidak dimasukkan dalam model.

\section{SIMPULAN}

Berdasarkan pada penjelasan yang telah dipaparkan dalam pembahasanbab sebelumnya, maka simpulan yang dapat ditarik dari penelitian ini adalahsebagai berikut:

1. Terdapat perbedaan yang signifikan antara Abnormal Return (AR) pada event sebelum dan setelah peristiwa kenaikan harga BBM. Dengan demikian menunjukkan bahwa pengumuman kenaikan harga BBM mempengaruhi keputusan investor dalam melakukan transaksi di pasar modal yang dilihat dari tingkat keuntungan. Hal ini terjadi dimungkinkan karena tanda- tanda atau sinyal dari pemerintah terhadap kenaikan harga BBM tersebut sudah muncul pada beberapa hari dan sudah diprediksi tanggal diberlakukannya kenaikan harga BBM tersebut.

2. Tidak terdapat perbedaan yang signifikan antara Trading Volume Activity (TVA) sebelum dan setelah pengumuman perubahan harga BBM pada event kenaikan harga BBM. Dengan demikian menunjukkan bahwa pengumuman kenaikan harga BBM tidak mempengaruhi keputusan investor dalam melakukan transaksi di pasar modal yang dilihat dari tingkat likuiditas.

3. Tidak terdapat perbedaan yang signifikan antara Abnormal Return (AR) pada event sebelum dan setelah peristiwa pengumuman penurunan harga BBM. Dengan demikian menunjukkan bahwa pengumuman penurunan harga BBM tidak mempengaruhi keputusan investor dalam melakukan transaksi di pasar modal yang dilihat dari tingkat keuntungan.

4. Tidak terdapat perbedaan yang signifikan antara Trading Volume Activity (TVA) sebelum dan setelah pengumuman perubahan harga BBM pada event penurunan harga BBM. Dengan demikian menunjukkan bahwa pengumuman kenaikan harga BBM tidak mempengaruhi keputusan investor dalam melakukan transaksi di pasar modal yang dilihat dari tingkat likuiditas.

\section{DAFTAR PUSTAKA}

Andarini, Diah. 2015. Analisis Reaksi Pasar Modal Terhadap Perubahan Harga BBM (Event Study Kenaikan dan Penurunan
Harga BBM pada Perusahaan Food and Beverages yang terdaftar di Bursa Efek Indonesia).Skripsi Fakultas Ekonomi dan Bisnis Universitas Brawijaya.

Brigham, Eugene F. and Houston, Joel F. 2006. Dasar-dasar Manajemen Keuangan, Buku 2 Edisi 10. Jakarta: Salemba Empat.

Chandra, Teddy. 2013. The Impact of Fuel Price Increase On Stock Price in Indonesia Stock Exchange. Journal of Economics, Business, and Accountancy Ventura, Vol.16, No.3, December 2013: hlm. 385398.

Dhaoui, Abderrazak and Khraief, Naceur. 2014. Empirical Linkage between Oil Price and Stock Market Returns and Volatility: Evidence from International Developed Markets. E-Journal, Discussion Paper, No.2014- 12, March 20, 2014.

Fahmi, Irham. 2013. Analisis Laporan Keuangan Cetakan Ke-2. Bandung:Alfabeta.

Ghozali, Imam. 2011. Aplikasi Analisis Multivariate dengan Program IBM SPSS19 Edisi 5. Semarang: Badan Penerbit Universitas Dipenogoro.

Hartono, Jogiyanto. 2013. Teori Portofolio dan Analisis Investasi Edisi Kedelapan. Yogyakarta: BPFE Yogyakarta.

Hikmah, Nur Utami. 2009. Pengaruh Pengumuman Kenaikan Harga BBM terhadap Abnormal Return dan Volume Perdagangan Saham (Studi Empiris padaPerusahaan-perusahaan yang masuk Jakarta Islamic Index).

Skripsi Fakultas Syariah Universitas Islam Negeri Sunan Kalijaga Yogyakarta.

Laksana dan Taman. 2014. Pengaruh Kenaikan Harga Bahan Bakar Minyak Bersubsidi Tahun 2013 Terhadap Abnormal Return Saham dan Trading Volume Activity Saham Pada Perusahaan yang Masuk Indeks LQ-45. E- Journal Akuntansi Universitas Negeri Yogyakarta, Vol.2, No.5, Tahun 2014.

Lutfiyani. 2014. Reaksi Pasar Terhadap Pengumuman Perubahan Harga BBM Pada Tanggal 1 Oktober 2005 dan Tanggal 22 Juni 2013. Skripsi Fakultas Ekonomi Universitas Negeri Semarang.

Marcus, Bodie Kane. 2014. Manajemen Portofolio dan Investasi. Jakarta: Salemba Empat

Marisca, Evi dan Wijaya, Trisnadi. 2014. Analisis Perbedaan Abnormal Return 
Sebelum dan Sesudah Pengumuman Kenaikan Harga Bahan Bakar Minyak (BBM) di Perusahaan LQ 45. Skripsi Jurusan Manajemen, Sekolah Tinggi Ilmu Ekonomi Multi Data Palembang.

Mohanty, Sunil K., Akhigbe, Aigbe, Al-Kyal, Tawfeek A., and Bugshan, Turki. 2013. Oil and stock Market Activity When Prices go Up and Down: The Case of The Oil and Gas Industry. Rev Quant Finan Acc (2013) 4: 253- 272.

Ningsih, Ervina Ratna. 2014. Analisis Reaksi Pasar Modal Indonesia Terhadap Peristiwa Kenaikan Harga BBM 22 Juni 2013 (Studi Kasus Pada Perusahaan LQ45 di BEI Tahun 2013). Skripsi Fakultas Ekonomi Universitas Negeri Semarang.

Parmadi, Ni Ketut Alit Rusmadewi, Adiputra, I Made Pradana, dan Dharmawan, Nym. Ari Surya. 2014. Analisis Reaksi Investor Terhadap Kenaikan Harga Bahan Bakar Minyak di Bursa Efek Indonesia (Event Study Terhadap Kenaikan Harga BBM Pada 21 Juni 2013). E-Journal Akuntansi Universitas Pendidikan Ganesha, Vol.2, No.1, Tahun 2014.

Ramadhan, Farid Siliwangi. 2014. Pengaruh Kenaikan Harga Bahan Bakar Minyak (BBM) Tahun 2013 Terhadap Investasi Saham (Event Study Saham pada Perusahaan Otomotif dan Komponen yang Terdaftar di Bursa Efek Indonesia).

Samsul, Mohamad. 2006. Pasar Modal \& Manajemen Portofolio. Jakarta:Erlangga.

Setyawan, St Tri Adi. 2006. Analisis Reaksi pasar Modal terhadap Kenaikan Harga BBM (Studi Kasus: di Bursa Efek Jakarta untuk Saham-saham LQ 45). Magister Manajemen Universitas Diponegoro Semarang.

Suarjana, I Wayan. 2011. Pengaruh Kebijakan Pemerintah Dalam Menurunkan Harga Bahan Bakar Minyak Terhadap Reaksi Pasar Saham di Bursa Efek Indonesia. Tesis Program Studi Manajemen, Program Pascasarjana Universitas Udayana Denpasar.

Suparsa, I Made Joni dan ratnadi, Ni Made. 2014. Perbedaan Abnormal Return dan Trading Volume Activity Atas Pengumuman Kenaikan Harga BBm Pada Saham yang Tergolong LQ 45. E-Jurnal Akuntansi Universitas Udayana 7.2 (2014): 382-389, ISSN: 2302-8556.
Tandelilin, Eduardus. 2010. Portofolio dan Investasi Teori dan Aplikasi, Edisi Pertama. Yogyakarta: Kanisius.

Zainafree, Golda. 2005. Reaksi Harga Saham terhadap Pengumuman Pembayaran Dividen Tunai di Bursa Efek Jakarta. Semarang. Tesis, Program Pasca Sarjana, Universitas Dipenogoro.

Sumber Internet

http://finance.yahoo.com/q/hp?s=ADHI.JK+Hist orical+Prices//

http://www.bapepam.go.id/pasar_modal/regulasi _pm/peraturan_pm/II/II.K.1.pdf//

http://www.idx.co.idid/beranda/unduhdata/ringkasan.aspx//

http://www.ksei.co.id/corporate_action_schedule /cash_dividend//

http://www.sahamok.com/bei/lq-45// 